\title{
PEMBUKTIAN PERZINAAN DALAM PERCERAIAN MENURUT AL-QUR'AN DAN HUKUM ACARA PERDATA
}

\author{
Mazro'atus Sa'adah \\ STIT Muhammadiyah Pacitan | mazroatus.saadah@yahoo.com.
}

\begin{abstract}
This article highlights about adultery as one of the strong reasons of divorce. The reason is however quite difficult to be legally proved. As mentioned in the Qur'an, verification of adultery is by presenting the four male witnesses. And it has been mentioned in the Qur'an chapter al-Nisa', verse 15, 16, 25 and in chapter al-Nur, verse 2, 4, 13 that the four male witnesses should be Muslim. In addition, Another way to prove adultery is lian as written in the Qur'an, chapter al-Nur, verse 6-9 that a husband who accuses his wife committing adultery while he does not have adequate evidence other than he himself, so he can prove it with a lian oath. It is also clearly stipulated in article 88 of Undang-Undang No.7 tahun 1989. While the proofs of adultery under the civil law of Religious Court other than the testimony of the four male witnesses are also by letter, oath, recognition, and conjecture.
\end{abstract}

Keywords: Verification, adultery, the Qur'an, the civil law

Abstrak: Artike ini membahas tentang pembuktian perzinaan dalam perceraian menurut al-Qur'an dan Hukum Acara Perdata. Perzinaan merupakan salah satu hal yang dapat dijadikan alasan perceraian, namun alasan ini sangat sulit pembuktiannnya. Dalam al-Qur'an disebutkan bahwa pembuktian zina adalah dengan menghadirkan empat orang saksi laki-laki, yang semuanya beragama Islam sebagaimana disebutkan dalam al-Qur'an yaitu QS. An-Nisa' (4) : 15 16, 25, an-Nur (24) : 2, 4, 13. Selain itu, terdapat cara lain untuk membuktikan perzinaan, seperti li'an sebagaimana dalam QS. an-Nur (24) ayat 6-9 tentang suami yang menuduh istrinya berzina sedangkan suami tidak mempunyai bukti selain dari ia sendiri yang mengetahuinya, maka suami dapat membuktikannya dengan mengucapkan sumpah li'an dan hal ini diatur dalam pasal 88 UU No.7 Tahun 1989. Sedangkan pembuktian perzinaan menurut hukum acara perdata 
Peradilan Agama adalah selain dengan persaksian empat orang saksi juga dengan surat, sumpah, pengakuan dan persangkaan.

Kata Kunci: Pembuktian, perzinaan, al-Qur'an, Hukum Acara Perdata

\section{Pendahuluan}

Ketika marak pembaharuan hukum Islam di berbagai negara Islam, hukum Islam (figh) yang selama ini terkesan statis menjadi berkembang sesuai dengan perkembangan zaman. Dalam hal ini Tahir Mahmood mengklasifikasikan pembaharuan hukum Islam ke dalam empat tipe yaitu intra-doctrinal reform, extra-doctrinal reform, regulatori dan kodifikasi. ${ }^{1}$ Indonesia sebagai negara yang mayoritas penduduknya beragama Islam tidak ketinggalan untuk melakukan reformasi hukum Islam, baik dari segi hukum materinya maupun hukum formalnya. Meskipun reformasi yang dilakukan bersifat regulatori yang lebih menonjolkan pengaturan administrasinya, paling tidak ada suatu kemajuan dalam memasukkan hukum Islam dalam hukum nasional. Dengan berlakunya UU No.1 Tahun 1974 tentang perkawinan, UU No. 7 Tahun 1989 tentang Peradilan Agama, dan Inpres No. 1 Tahun 1991 tentang Kompilasi Hukum Islam (KHI), maka segala ketentuan hukum Islam yang berkaitan dengan persoalan perkawinan, perceraian, waris, hibah dan wasiat harus tunduk pada ketentuan UU tersebut.

Dengan dikeluarkannya UU No.7 Tahun 1989, maka Pengadilan Agama sebagai pengadilan bagi orang-orang Islam mempunyai kedudukan dan wewenang yang sama dengan Pengadilan Negeri. Sebelum itu putusan Pengadilan Agama belum dianggap mempunyai kekuatan hukum tetap kecuali kalau telah mendapat pengesahan dari Pengadilan Agama. Meskipun demikian dalam hukum acaranya, Peradilan Agama memberlakukan hukum acara perdata yang berlaku di Peradilan Umum yaitu HIR dan RBG kecuali yang telah diatur khusus dalam

' Tahir Mahmood, Family Law Reform in The Modern World, (Bombay: N.M. Tripathi PVT. LTD., 1972), 267-269. 
Undang-Undang. Pasal 54 UU No.7 Tahun 1989 menyatakan bahwa "Hukum acara yang berlaku pada Pengadilan dalam lingkungan Peradilan Agama adalah hukum acara perdata yang berlaku pada pengadilan dalam lingkungan Peradilan Umum, kecuali yang telah diatur secara khusus dalam undang-undang ini".

Hukum pembuktian merupakan bagian yang penting dan tidak bisa dipisahkan dari hukum acara peradilan. Akan tetapi karena ketentuan dalam pasal 54 tersebut tidak memberikan rumusan atau penjelasan lain, maka asumsi hukum pembuktian yang berlaku di Peradilan Umum akan berlaku pula bagi Peradilan Agama sebagai Peradilan Khusus bagi orang-orang Islam. Padahal dalam kasus perceraian dengan alasan zina terdapat ketentuan khusus dalam UU No.7 Tahun 1989 termasuk hukum acara pembuktiannya yang berbeda dengan ketentuan hukum acara Peradilan Umum. Oleh karena itu, tulisan ini membahas pembuktian perzinaan dalam perceraian menurut alQur'an dan hukum acara perdata Peradilan Agama. Hal ini sangat penting untuk dibahas karena perceraian dengan alasan zina sangat sulit sekali pembuktiannya dan bisa jadi hanya dijadikan alasan "pura-pura" bagi suami istri untuk berpisah. Dalam pembahasan ini difokuskan pada pembuktian dengan saksi, pengakuan dan persangkaan. Sedangkan pembuktian dengan sumpah tidak masuk dalam pembahasan ini, karena alat bukti sumpah akan mengarah pada perkara li'an. Meskipun hal ini satu rangkaian, namun pembahasan ini hanya dibatasi pada persoalan pembuktian perzinaan saja.

\section{Normatifitas Perceraian Di Indonesia}

Perceraian atau dalam bahasa Arab disebut talaq berasal dari kata itlaq yang secara bahasa berarti melepaskan (irsal) dan meninggalkan (at-tark). Sedangkan secara istilah kata talaq didefinisikan dengan melepaskan ikatan perkawinan dan 
berakhirnya hubungan suami-istri. ${ }^{2}$ Meskipun perceraian merupakan perbuatan halal namun perbuatan ini sangat dibenci oleh Allah ${ }^{3}$ dan sekaligus perbuatan yang paling jelek. Sebagai suatu perbuatan yang dibenci, maka perceraian sedapat mungkin dihindari dan hanya diperbolehkan karena alasan darurat, terpaksa dan dalam keadaan khusus. Sebenarnya perceraian ini termasuk perbuatan yang kufur ni'mat, sehingga jika tidak ada alasan-alasan dibolehkannya cerai maka perbuatan itu menjadi tidak halal.

Kebanyakan kasus perceraian tidak disebabkan karena alasan-alasan yang sesuai, tetapi dengan alasan-alasan yang masih mentah, yaitu bahwa alasan-alasan itu hanya sepele dan tidak sepatutnya menyebabkan perceraian. Suami dan istri karena sifatnya yang terlalu mementingkan diri sendiri mungkin akan membesar-besarkan masalah kecil dan memutuskan bahwa kehidupan perkawinan mereka harus diakhiri. Untuk menghindari perceraian yang semena-mena dan tanpa alasan maka sejak dikeluarkannya UU No.1 Tahun 1974 sampai munculnya Kompilasi Hukum Islam, perceraian harus dilakukan di depan sidang pengadilan. Dengan demikian dari segi pengaturan administrasinya hukum perceraian telah mengalami pembaharuan dari hukum Islam (figh) yang cukup dengan mengucapkan kata talak tanpa disidang di depan pengadilan menjadi keharusan untuk mengucapkannya di sidang pengadilan dengan prosedur beracara yang berlaku. Perceraian dapat terjadi karena talak (cerai talak) dan karena gugatan perceraian (cerai gugat).

Untuk menghindari perceraian yang main-main, maka pihakpihak yang akan mengajukan gugatan atau permohonan cerai

\footnotetext{
2 Sayyid Sabiq, Fiqh as-Sunnah, (Beirut: Dar al-Fikr, I 403 H/I 983 M), 206.

${ }^{3}$ Telah menceritakan kepada kami Katsir bin 'Ubaid, telah menceritakan kepada kami Muhammad bin Khalid, dari Mu'arrif bin Washil, dari Muharib bin Ditsar, dari Ibnu 'Umar -radhiyallahu 'anhuma-, dari Nabi saw, beliau bersabda, "Perkara halal yang dibenci Allah Ta'ala adalah thalaq (perceraian)." [Sunan Abu Dawud 3/505].
} 
harus mengajukan alasan-alasan atau dalil yang membolehkannya untuk bercerai. Dalam pasal 19 PP No.9 Tahun 1975 dinyatakan bahwa perceraian dapat terjadi karena alasan atau alasan-alasan: (a) salah satu pihak berbuat zina atau menjadi pemabuk, pemadat, penjudi, dan lain sebagainya yang sukar disembuhkan, (b) salah satu pihak meninggalkan pihak lain selama 2 (dua) tahun berturutturut tanpa izin pihak lain dan tanpa alasan yang sah atau karena hal lain di luar kemampuannya, (c) salah satu pihak mendapat hukuman penjara 5 (lima) tahun atau hukuman yang lebih berat setelah perkawinan berlangsung, (d) salah satu pihak melakukan kekejaman atau penganiayaan berat yang membahayakan pihak yang lain, (e) salah satu pihak mendapat cacat badan atau penyakit dengan akibat tidak dapat menjalankan kewajibannya sebagai suami/istri, (f) antara suami dan istri terus-menerus terjadi perselisihan dan pertengkaran dan tidak ada harapan akan hidup rukun lagi dalam rumah tangga. Kemudian dalam KHI pasal 116 ditambahkan dua hal yaitu (g) suami melanggar ta'lik talak, (h) peralihan agama atau murtad yang menyebabkan terjadinya ketidakrukunan dalam rumah tangga.

\section{Perzinaan sebagai Alasan Perceraian}

Dalam UU No.1 Tahun 1974 pasal 39 ayat (2) disebutkan bahwa untuk melakukan perceraian harus ada cukup alasan. Menurut ketentuan pasal 19 PP No.9 Tahun 1975 (pelaksanaan dari UU No.1 Tahun 1974 tentang perkawinan), perbuatan zina dapat dijadikan alasan untuk suami istri untuk bercerai baik di Peradilan Umum maupun Peradilan Agama. Namun dalam banyak kasus perceraian jarang sekali yang menggunakan dalil zina, paling-paling memakai kata serong atau selingkuh. Mungkin dalam bahasa sehari-hari perkataan serong mengandung konotasi zina. Namun dalam segi hukum serong tidak sama persis dengan zina, karena dalam perkataan serong itu sendiri masih terkandung kesamaran dan keraguan. Masih dapat dipertanyakan apakah perbuatan serong yang dilakukan sudah benar-benar sampai pada 
tingkat berhubungan kelamin secara fisik dan biologis. Hal ini dikarenakan betapa sulitnya pembuktian zina tersebut, apalagi dalam hukum Islam harus disaksikan empat orang laki-laki yang semuanya beragama Islam.

Pembuktian perzinaan di muka pengadilan sangat sulit karena definisi zina yang masih belum jelas. Apakah asal sudah ketemu ujung persunatan laki-laki (glans, penis; hashafah) dengan ujung persunatan perempuan (clitoris; bazr) di luar nikah sah dapat dikatakan zina, ataukah disyaratkan masuknya alat kelamin lakilaki (penis; zakar) ke dalam alat kelamin perempuan (vulva; farj)? Lalu bagaimana dengan watha' subhat, persetubuhan dipaksa, persetubuhan suami istri yang dibatalkan karena keduanya saudara sesusuan dan lain sebagainya, apakah juga termasuk zina? Menurut Ibn Rusyd, zina adalah persetubuhan yang terjadi di luar nikah yang sah dan bukan karena nikah subhat serta bukan karena milk al-yamin. ${ }^{4}$ Definisi inipun tidak memberikan kejelasan untuk mengklaim zina pada persoalan pertama.

Ketentuan yang terdapat dalam surat an-Nur (24) ayat 4 mengenai h\}ad zina mengandung asas "in flagrante delicto" yaitu perbuatan zina yang dituduhkan kepada seseorang akan dibuktikan lewat alat bukti saksi. Asas in flagrante delicto dalam kasus perkara menyangkut perceraian, pada umumnya dipegang secara teguh dalam praktek peradilan. Nampaknya dalam kehidupan masyarakat sendiri tumbuh suatu kesadaran yang membenarkan tuduhan zina harus dibarengi dengan pembuktian kesaksian secara in flagrante delicto dan hal ini tentunya pembuktian seperti ini sangat sulit. Sehingga asas ini memang perlu diterapkan untuk menghindari munculnya kekacauan dalam kehidupan bermasyarakat. Sebab zina bukan hanya menyangkut hak suami istri atau hak dari dua orang yang melakukannya saja, tetapi juga menyangkut hak masyarakat (publik).

${ }^{4}$ Al-Imam al-Qadi Abu al-Walid Muhammad ibn Ahamad ibn Muhammad ibn Ahmad ibn Rusyd, Bidayah al-Mujtahid wa Nihayah al-Maqasid, (Semarang: Toha Putera, t.t.), 324. 


\section{Pembuktian Perzinaan Menurut Al-Qur'an}

Menurut ketentuan al-Qur'an surat an-Nisa' (4) ayat 15 dan $16^{5}$ dijelaskan bagi perempuan yang melakukan zina wajib dibuktikan dengan empat orang saksi laki-laki yang semuanya beragama Islam. Hukuman bagi perempuan tersebut adalah dikurung di dalam rumah sampai ia mati atau sampai Allah memberikan jalan lain. Ketentuan ini kemudian dinasakh oleh ketentuan surat an-Nur (24) ayat $2^{6}$ bahwa hukumannya adalah had zina dengan dicampuk 100 kali. Ketentuan ini juga berlaku bagi laki-laki yang berzina. ${ }^{7}$ Namun ayat 2 ini masih bersifat umum, artinya belum membedakan antara yang muhsan dan ghairu muhsan, ${ }^{8}$ bahkan menurut Mujahid ketentuan ini juga berlaku bagi perempuan lesbi. ${ }^{9}$

${ }^{5}$ Dan (terhadap) Para wanita yang mengerjakan perbuatan keji, hendaklah ada empat orang saksi diantara kamu (yang menyaksikannya). Kemudian apabila mereka telah memberi persaksian, maka kurunglah mereka (wanita-wanita itu) dalam rumah sampai mereka menemui ajalnya, atau sampai Allah memberi jalan lain kepadanya. Dan terhadap dua orang yang melakukan perbuatan keji di antara kamu, maka berilah hukuman kepada keduanya, kemudian jika keduanya bertaubat dan memperbaiki diri, maka biarkanlah mereka. Sesungguhnya Allah Maha Penerima taubat lagi Maha Penyayang.

${ }^{6}$ Perempuan yang berzina dan laki-laki yang berzina, Maka deralah tiap-tiap seorang dari keduanya seratus dali dera, dan janganlah belas kasihan kepada keduanya mencegah kamu untuk (menjalankan) agama Allah, jika kamu beriman kepada Allah, dan hari akhirat, dan hendaklah (pelaksanaan) hukuman mereka disaksikan oleh sekumpulan orang-orang yang beriman.

${ }^{7}$ Muhammad 'Abd al-Mun'im al-Jamal, at-Tafsir al-Farid li al-Qur'an al-Majid, (Kairo: Al-Azhar, $1390 \mathrm{H} / \mathrm{I} 970 \mathrm{M}), \mathrm{I}-16$.

${ }^{8}$ Ada fuqaha yang menggunakan kata bikr dan zakr untuk perempuan dan laki-laki yang belum pernah kawin dan atau tidak dalam keadaan bersuami atau beristri, serta kata sayyib atau syaikhah dan syaikh untuk perempuan dan laki-laki yang sudah pernah kawin dan atau dalam keadaan bersuami atau beristri. Sebutan tersebut bisa mengelirukan, karenanya dengan memperhatikan kitab-kitab tafsir, hadis dan figh lebih baik digunakan saja kata ghairu muhsan untuk yang dimaksudkan pertama dan kata muhsan untuk yang kedua, sebab yang disasarkan oleh ayat sebenarnya adalah perempuan atau laki-laki yang tidak dalam keadaan bersuami atau beristri dan perempuan atau laki-laki yang dalam keadaan bersuami atau beristri.

${ }^{9}$ Hukuman bagi laki-laki atau perempuan muhsan yang melakukan zina adalah merupakan aturan khusus (lex specialis) yaitu berupa pemberatan dari had zina 100 kali cambuk menjadi hukuman rajam. Rajam arti asalnya dilempar dengan batu besar hingga mati dan prakteknya di zaman Rasulullah maupun khalifah rasyidin bahwa si terhukum dikubur setengah badan di tanah lantas oleh umum dilempari dengan batu hingga mati. Lihat Roihan A. Rasyid, "Penyelarasan Diberlakukannya Hukum Acara Perdata Peradilan Umum sebagai Hukum Acara Peradilan Agama Khusus di Segi Pembuktian Zina", dalam Mimbar Hukum, 37. 
Kemudian menurut ketentuan al-Qur'an surat an-Nur (24) ayat $4^{10}$ dan $13^{11}$, tuduhan bagi perempuan muhsan yang melakukan zina wajib dibuktikan dengan empat orang saksi lakilaki yang semuanya beragama Islam. Penuduh bisa lepas dari hukuman h\}ad menuduh zina (qazaf) sebanyak 80 kali cambuk kalau tuduhannya terbukti. Sedangkan dalam surat an-Nisa' (4) ayat $25^{12}$ dijelaskan terhadap hamba sahaya yang muhsan yang melakukan zina maka ancaman hukumannya adalah separuh dari hukuman orang merdeka, tetapi ayat tersebut tidak menyebut cara pembuktiannya. ${ }^{13}$

Dari beberapa ayat yang disebutkan di atas, ada permasalahan yang perlu dirumuskan dan dikaji tentang saksi empat orang yang semuanya beragama Islam tersebut. Kalau saksi empat orang itu sebagai syarat untuk pembuktian zina dan sekaligus sebagai syarat hukum untuk sahnya menjatuhkan hukuman had zina, berarti zina hanya dapat dibuktikan dengan kesaksian empat orang laki-laki yang semuanya beragama Islam.

${ }^{10}$ Dan orang-orang yang menuduh wanita-wanita yang baik-baik (berbuat zina) dan mereka tidak mendatangkan empat orang saksi, maka deralah mereka (yang menuduh itu) delapan puluh kali dera, dan janganlah kamu terima kesaksian mereka buat selama-lamanya. Dan mereka itulah orang-orang yang fasik.

II Mengapa mereka (yang menuduh itu) tidak mendatangkan empat orang saksi atas berita bohong itu? Oleh karena mereka tidak mendatangkan saksi-saksi, maka mereka itulah pada sisi Allah orang- orang yang dusta.

12 Dan Barangsiapa diantara kamu (orang merdeka) yang tidak cukup perbelanjaannya untuk mengawini wanita merdeka lagi beriman, ia boleh mengawini wanita yang beriman, dari budakbudak yang kamu miliki. Allah mengetahui keimananmu; sebahagian kamu adalah dari sebahagian yang lain, karena itu kawinilah mereka dengan seizin tuan mereka, dan berilah maskawin mereka menurut yang patut, sedang merekapun wanita-wanita yang memelihara diri, bukan pezina dan bukan (pula) wanita yang mengambil laki-laki lain sebagai piaraannya; dan apabila mereka telah menjaga diri dengan kawin, kemudian mereka melakukan perbuatan yang keji (zina), Maka atas mereka separo hukuman dari hukuman wanita-wanita merdeka yang bersuami. (Kebolehan mengawini budak) itu adalah bagi orang-orang yang takut kepada kemasyakatan menjaga diri (dari perbuatan zina) di antara kamu, dan kesabaran itu lebih baik bagimu. dan Allah Maha Pengampun lagi Maha Penyayang.

13 Hamba sahaya perempuan yang sudah beriman tidak boleh begitu saja dicampuri oleh tuannya kecuali melalui nikah terlebih dulu. Hukuman separuh dari hukuman orang merdeka bagi hamba sahaya yang muhsan melakukan zina karena sukar memperhitungkan separuh rajam maka ditetapkan seperdua dari 100 kali cambuk.

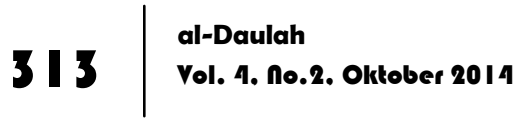


Kalau saksi empat orang tersebut hanya sebagai syarat hukum untuk sahnya menjatuhkan had zina, maka pembuktian zina boleh dengan cara lain tetapi untuk pembuktian menjatuhkan hukuman h\}ad zina wajib dengan empat orang saksi laki-laki yang semuanya beragama Islam.

Selanjutnya dilihat dari konteks ayat maka inti sasarannya adalah hukuman had sebagaimana yang ditunjuk dalam surat anNisa' (4) ayat 16, an-Nur (24) ayat 2 dan 4. Dengan demikian konteks atau sasaran inti dari semua ayat di atas dapat dipahamkan bahwa pembuktian dengan kesaksian empat orang laki-laki yang semuanya beragama Islam adalah untuk syarat sahnya menjatuhkan hukuman zina dan bukan untuk syarat pembuktian zina, karena masih ada cara lain untuk membuktikannya selain dengan empat orang saksi. Hal ini bisa dilihat dari ketentuan surat an-Nur (24) ayat 6-914 tentang suami yang menuduh istrinya berzina sedangkan suami tidak mempunyai bukti selain dari ia sendiri yang mengetahuinya, maka suami dapat membuktikannya dengan mengucapkan sumpah li'an dan hal ini diatur dalam pasal 88 UU No.7 Tahun 1989. Dengan demikian pembuktian zina tidak hanya melalui satu cara saja.

\section{Pembuktian Perzinaan menurut Hukum Acara Perdata Peradilan} Agama

\section{Hukum Acara Perdata Peradilan Agama}

Hukum acara perdata adalah rangkaian peraturanperaturan yang memuat cara bagaimana orang harus bertindak terhadap dan di muka pengadilan dan cara bagaimana pengadilan itu harus bertindak satu sama lain

${ }^{14}$ Dan orang-orang yang menuduh isterinya (berzina), padahal mereka tidak ada mempunyai saksi-saksi selain diri mereka sendiri, maka persaksian orang itu ialah empat kali bersumpah dengan nama Allah. Sesungguhnya Dia adalah termasuk orang-orang yang benar. Dan (sumpah) yang kelima: bahwa la'nat Allah atasnya, jika dia termasuk orang-orang yang berdusta. Istrinya itu dihindarkan dari hukuman oleh sumpahnya empat kali atas nama Allah Sesungguhnya suaminya itu benar-benar termasuk orang-orang yang dusta. Dan (sumpah) yang kelima: bahwa laknat Allah atasnya jika suaminya itu termasuk orang-orang yang benar. 
untuk melaksanakan berjalannya peraturan-peraturan hukum perdata. ${ }^{15}$ Bila hal ini dihubungkan dengan tugas dan wewenang pengadilan maka pada dasarnya hukum acara itu merupakan suatu proses penerimaan, pemeriksaan, penyidangan, pemutusan dan penyelesaian perkara yang diajukan kepadanya. ${ }^{16}$ Proses pembuktian sendiri merupakan rangkaian dari proses pemeriksaan dan penyidangan.

Ketentuan tentang hukum acara di Pengadilan Agama terdapat dalam Bab IV UU No.7 Tahun 1989 mulai pasal 54 sampai dengan pasal 105. Menurut pasal 54 hukum acara yang berlaku pada pengadilan dalam lingkungan Peradilan Agama adalah Hukum Acara Perdata yang berlaku pada Pengadilan dalam lingkungan Peradilan Umum, kecuali yang telah diatur secara khusus dalam undang-undang ini. Dari ketentuan ini dapat dipahami bahwa proses beracara termasuk tata cara pemeriksaan di lingkungan Peradilan Agama sama dengan yang berlaku di Peradilan Umum kecuali yang ditentukan khusus oleh undang-undang PA. Kaitannya dengan perceraian yang berdalih zina ini, UU Pengadilan Agama telah mengatur hukum acaranya secara khusus yaitu pasal 87-88. Hal ini dikarenakan perkara zina merupakan hal yang sangat rumit pembuktiannya dan juga ada beberapa hal yang berbeda antara hukum Islam dan hukum Barat.

Hukum acara perdata yang berlaku pada Peradilan Umum adalah HIR (Het-Herziene Inlandsche Reglement), RBG (Rechts Reglement Buitengewesten), BRv (Reglement op de Burgerlijke Rechtsvordering), dan BW (Burgelijke Wetboek). ${ }^{17}$

${ }^{15}$ Wirjono Prodjodikoro R., Hukum Acara Perdata di Indonesia, (Jakarta: Sumur Bandung, 1980), 13.

${ }^{16}$ Cik Hasan Bisri, Peradilan Agama di Indonesia, (Jakarta: PT. Raja Grafindo Persada, 1998), 226.

${ }^{17}$ HIR dan RBG adalah hukum acara peradilan untuk Landraad (sekarang Pengadilan Negeri) yang masing-masing untuk daerah Jawa-Madura dan luar Jawa-Madura. BRv adalah hukum acara peradilan untuk Raad van Justitie yaitu pengadilan tingkat pertama untuk orang Eropa/dipersamakan dan atau pengadilan tingkat banding bagi bumi putera (sekarang Pengadilan 
Keempat-empatnya sejak awal pembuatannya dipergunakan untuk mengabdi kepada hukum materiil yang berlaku bagi Landraad atau Raad van Justitie (Pengadilan Negeri) yang jelas irrelevant (tidak peduli) terh\}adap hukum Islam. Pertimbangan diberlakukannya hukum acara perdata Peradilan Umum sebagai hukum acara perdata Peradilan Agama walaupun tidak secara tegas dinyatakan dalam UU No.7 Tahun 1989 tetapi dari penjelasannya dapat ditangkap karena ada persamaan dari segi sifat keperdataannya meskipun tidak secara keseluruhan. Sebut saja mengenai kasus jatuhnya putusan perceraian PA dan PN yang mendapat banding atau kasasi. Di Pengadilan Agama hukum materiil cerai beserta segala akibatnya tetap terhitung sejak tanggal ditetapkannya cerai di pengadilan tingkat pertama, sedangkan di Peradilan Umum cerai baru dihitung sejak dicatatkan perceraian pada Kantor Catatan Sipil setelah diputus oleh Mahkamah Agung. Begitu juga dengan pembuktian zina, dalam hukum acara perdata Peradilan Umum hanya diperlukan dua orang saksi, sedangkan di Peradilan Agama harus empat orang saksi sesuai dengan ketentuan al-Qur'an. Untuk lebih lanjutnya mengenai pembuktian zina ini, perlu ditegaskan terlebih dulu alat-alat bukti dalam hukum acara yaitu saksi, surat, persangkaan, dan sumpah yang selanjutnya akan diterapkan pada pembuktian zina dalam Peradilan Agama.

Negeri). BW adalah hukum perdata materiil dan sebagian perdata formil untuk orang-orang Eropa/dipersamakan dan orang Timur Asing. Roihan A. Rasyid, "Penyelarasan Diberlakukannya Hukum Acara Perdata Peradilan Umum sebagai Hukum Acara Peradilan Agama Khusus di Segi Pembuktian Zina", dalam Mimbar Hukum: Aktualisasi Hukum Islam, No.7, Tahun III, (Jakarta: Yayasan al-Hikmah \& Direktorat Pembinaan Badan Peradilan Agama Islam, 1992), 35. 


\section{Pembuktian Zina menurut Hukum Acara Perdata PA}

a. Dengan Empat Orang Saksi

Pembuktian zina dalam hukum acara perdata Peradilan Umum hanya diperlukan dua orang saksi, sedangkan di Peradilan Agama harus empat orang saksi sesuai dengan ketentuan al-Qur'an yaitu ketentuan alQur'an surat an-Nur (24) ayat 4 dan 13, tuduhan bagi perempuan muhsan yang melakukan zina wajib dibuktikan dengan empat orang saksi laki-laki yang semuanya beragama Islam.

b. Dengan Pengakuan

Hukum acara perdata di Peradilan Agama dan Peradilan umum sama-sama memandang pengakuan sebagai alat bukti yang mengikat. Permasalahannya apakah boleh dan berlaku mengikat suatu pengakuan secara utuh tanpa syarat dan tanpa dipecah-pecah, katakanlah diucapkan di muka sidang pengadilan, bahwa seseorang mengaku telah melakukan zina?

Pasal 87 ayat 1 UU No.7 Tahun 1989 membenarkan keterbuktian perbuatan zina berdasar pengakuan tergugat, yang bunyinya "......pemohon atau penggugat tidak dapat melengkapi bukti-bukti dan termohon atau tergugat menyanggah alasan tersebut.....". kalimat ini dapat dirumuskan bahwa penggugat wajib membuktikan dalil gugat apabila termohon atau tergugat "menyanggah" dalil gugat, sebaliknya jika termohon atau tergugat "mengakui" dalil zina maka pemohon atau penggugat tidak dibebani wajib bukti dan dianggap telah berhasil membuktikan dalil gugat.

Rumusan tersebut merupakan prinsip pembuktian yang diatur dalam pasal 163 HIR atau 283 RBG. Prinsip ini juga menjadi patokan doktrin pembebanan wajib bukti yang diatur dalam pasal 1865 KUH Perdata yaitu "siapa yang mendalilkan sesuatu hak atau peristiwa baik hal itu 
bertujuan untuk mengokohkan maupun untuk membantah dalil, wajib bukti dibebankan kepadanya". Kemudian jika prinsip tersebut dihubungkan dengan ketentuan pasal 174 HIR atau 311 RBG yang menyatakan bahwa pengakuan murni dari pihak lawan melenyapkan wajib beban bukti kepada pihak lain, dan ditegaskan dalam pasal 1925 KUH Perdata yaitu pengakuan yang dilakukan di muka hakim (sidang pengadilan) merupakan pembuktian yang sempurna terh\}adap apa yang telah diakuinya, serta pasal 1926 dan 1927 KUH Perdata yang menyatakan bahwa nilai kekuatan pembuktian pengakuan tidak hanya bersifat "sempurna" (volledig) tapi juga "mengikat" (bindende bewijskracht) dan "menentukan" (beslisande bewijskracht), maka prinsip ini sesuai dengan asa pembuktian zina dalam surat an-Nur (24) ayat 4,6,7.

Harus diakui menerapkan pengakuan sebagai alat bukti yang sempurna, mengikat dan menentukan dalam perkara perceraian atas alasan zina bisa menimbulkan terjadinya perceraian berdasarkan kesepakatan suami istri (cerai buatan) walaupun sebenarnya keduanya tidak pernah berzina. Jika bertitik tolak dari prinsip nilai kekuatan yang terkandung dalam pengakuan tersebut, berarti tidak ada pilihan lain bagi hakim selain daripada mengabulkan gugatan. Tetapi penerapan nilai kekuatan pembuktian yang terkandung dalam alat bukti pengakuan, jangan diterapkan secara mutlak dan membabi buta. Oleh karena itu, hakim sebagai pencipta hukum dalam hal ini harus melihat pada kasus perkaranya. ${ }^{18}$

c. Dengan Persangkaan

18 M. Yahya Harahap, Kedudukan Kewenangan dan Acara Peradilan Agama Undang-Undang No.7 Tahun 1989, (ttp.: Pustaka Kartini, 1997), 323. 
Bukti dengan persangkaan (al-qarinah al-wadlihah atau vermoeden) ada dua macam yaitu persangkaan hakim dan persangkaan undang-undang. Persangkaan hakim adalah kesimpulan hakim yang ditarik atau sebagai hasil dari pemeriksaan sidang. Sedangkan persangkaan Undang-undang adalah kesimpulan yang ditarik oleh hakim berdasarkan ketentuan yang terdapat dalam Undang-undang. ${ }^{19}$ Menurut Prof. R. Subekti persangkaan hakim merupakan yurisprudensi tetap (konstan). ${ }^{20}$

Dalam Islam, persangkaan ini pernah digunakan oleh Rasulullah, sahabat dan ahli hukum Islam. Khalifah Umar bin Khattab misalnya pernah menghukum had seorang perempuan hamil padahal ia tidak bersuami dan bukan hamba sahaya. ${ }^{21}$ Dengan demikian persangkaan melakukan zina dapat dimungkinkan. Hal ini tentunya perlu memformulasikan sifat atau bentuk dari peristiwa atau kejadian yang menjadi dasar persangkaan tersebut sesuai dengan perkembangan ilmu pengetahuan dan teknologi..22 Persangkaan zina karena hamil dalam keadaan tidak bersuami masih bisa disebabkan berbagai kemungkinan lain yang akan mempengaruhi hukum zina atau tidak seperti karena dipaksa, karena watha' syubhat, karena masa kandungan yang amat lama bagi perenpuan yang diceraikan dan lain-lain. Karena itulah para ahli hukum Islam tidak sepakat kehamilan semata untuk dijadikan bukti memberlakukan h\}ad zina. Perbuatan zina

19 Roihan A. Rasyid, "Penyelarasan Diberlakukannya Hukum Acara Perdata Peradilan Umum sebagai Hukum Acara Peradilan Agama Khusus di Segi Pembuktian Zina" dalam Mimbar Hukum., 41.

${ }^{20}$ R. Subekti, Hukum Pembuktian, (Jakarta: Pradnya Paramita, 1975), 44.

${ }^{21}$ Jalal ad-Din as-Suyuti, Muwatta' Imam Malik, (Mesir: Mustafa al-Baby al-Halaby, 195I), 168.

22 Perempuan sekarang ini bisa hamil tanpa melalui hubungan senggama baik secara langsung seperti inseminasi buatan maupun bayi tabung, dan secara tidak langsung seperti handuk seorang laki-laki yang bermani kemudian disekakan ke dalam kemaluan perempuan atau dengan mandi dalam satu bak mandi. Haliman, Hukum Pidana Syariat Islam, (Jakarta: Bulan Bintang, 1980), 399-400. 
tidak dapat didasarkan dari suatu hasil konklusi. Apalagi berupa kesimpulan yang ditarik berdasar dugaan dari suatu keadaan atau peristiwa. ${ }^{23}$

Sebagai al-qarinah al-wadlihah (persangkaan yang jelas) maka persangkaan yang dapat diggunakan sebagai alat bukti adalah hal-hal yang meyakinkan dan tidak patut akan dibantah oleh manusia yang normal (berakal sehat dan cerdas). Misalnya dua orang yang melakukan foto bugil berdua dan masuk dalam kamar hotel. Contoh ini bisa jadi masuk akal pasti telah terjadi perbuatan zina. Dengan demikian persangkaan dapat dijadikan alat bukti perbuatan zina jika peristiwanya masuk akal, dan hakim tetap harus membuktikan dengan alat-alat bukti yang lain untuk mendukung persangkaannya tersebut.

\section{Penutup}

Hukum acara yang berlaku di PA adalah hukum acara yang berlaku di Pengadilan Umum kecuali yang ditentukan khusus dalam UU No.7 Tahun 1989 seperi tentang perceraian dengan alasan zina. Oleh karenanya pembuktian zina dalam kasus perceraian di PA harus mempedomani ketentuan UU ini yang berdasarkan Islam.

Pembuktian zina menganut asas in flagrante delicto, sehingga pembuktiannya dirasakan sangat sulit. Empat orang saksi harus benar-benar melihat kejadiannya dan tidak dibolehkan untuk mengambil kesimpulan dari suatu peristiwa. Bukti dengan pengakuan meskipun merupakan bukti yang sempurna, namun hakim perlu menimbang kembali pengakuan suami atau istri. Jika tidak, akan dikhawatirkan perceraian buatan dengan persetujuan para pihak yang tanpa alasan ingin bercerai. Bukti dengan persangkaan dibolehkan asalkan persangkaan itu bisa masuk akal dan sering ada kasus yang sama.

\footnotetext{
${ }^{23}$ M. Yahya Harahap, Kedudukan, 321.
} 
Saran bagi suami istri, hendaknya tidak menggunakan dalil cerai dengan alasan zina, karena pembuktiannya sangat sulit dan jika bersumpah akan terkena hukum qazaf serta putusannya secara li'an yang berakibat putus selamanya. Bagi hakim, hendaknya lebih teliti lagi dalam membuktikan dalil-dalil gugat, agar tidak terkesan cerai itu mudah dan bisa dibuat oleh suami istri.

\section{Daftar Pustaka}

Bisri, Cik Hasan. Peradilan Agama di Indonesia. Jakarta: PT. Raja Grafindo Persada, 1998.

Haliman. Hukum Pidana Syari'at Islam. Jakarta: Bulan Bintang, 1980. Harahap, M. Yahya. Kedudukan Kewenangan dan Acara Peradilan Agama Undang-Undang No.7 Tahun 1989. ttp.: Pustaka Kartini, 1997.

Jamal (al-), Muhammad 'Abd al-Mun'im. at-Tafsir al-Farid li alQur'an al-Majid. Kairo: Al-Azhar, 1390 H/1970 M.

Mahmood, Tahir. Family Law Reform in The Modern World. Bombay: N.M. Tripathi PVT. LTD., 1972.

R., Wirjono Prodjodikoro. Hukum Acara Perdata di Indonesia. Jakarta: Sumur Bandung, 1980.

Rasyid, Roihan A. "Penyelarasan Diberlakukannya Hukum Acara Perdata Peradilan Umum sebagai Hukum Acara Peradilan Agama Khusus di Segi Pembuktian Zina", dalam Mimbar Hukum: Aktualisasi Hukum Islam, No.7, Tahun III, Jakarta: Yayasan al-Hikmah \& Direktorat Pembinaan Badan Peradilan Agama Islam, 1992.

Rusyd, Al-Imam al-Qadi Abu al-Walid Muhammad ibn Ahmad ibn Muhammad ibn Ahmad ibn. Bidayah al-Mujtahid wa

Nihayah al-Maqasid. Semarang: Toha Putera, t.t.

Sabiq, Sayyid. Fiqh as-Sunnah. Beirut: Dar al-Fikr, 1403 H/1983 M. Subekti, R. Hukum Pembuktian. Jakarta: Pradnya Paramita, 1975. Suyuti (as-), Jalal ad-Din. Muwatta' Imam Malik. Mesir: Mustafa alBaby al-Halaby, 1951. 